\title{
Secondary Metabolites Approach to Study the Bio-Efficacy of Trichoderma asperellum Isolates in India
}

\author{
N. Srinivasa ${ }^{1 *}$, S. Sriram ${ }^{2}$, Chandu Singh ${ }^{3}$ and K.S. Shivashankar ${ }^{2}$ \\ ${ }^{1}$ Division of Plant Pathology, ICAR-Indian Agricultural Research Institute (IARI), \\ Pusa campus, New Delhi-11012, India \\ ${ }^{2}$ Division of Plant Pathology and Physiology, ICAR-Indian Institute of Horticultural Research, \\ Bangalore 560089, India \\ ${ }^{3}$ Seed Production Unit, ICAR-Indian Agricultural Research Institute (IARI), Pusa campus, \\ New Delhi-11012, India \\ *Corresponding author:
}

\section{Keywords}

Trichoderma asperellum,

Metabolomics, secondary metabolites, antifungal compounds, GC-MS, LC-MS, Sclerotium rolfsii, retention time.

\section{Article Info}

Accepted:

12 April 2017

Available Online:

10 May 2017
10 isolates of Trichoderma asperellum was used for characterization of secondary metabolites through gas chromatography-mass spectrometry (GC-MS) and liquid chromatography-mass spectrometry (LC-MS) analysis to establish valid correlation between the production of antifungal metabolites and their bio-efficacy as BCAs. The investigation revealed that the culture filtrate of $T$. asperellum isolates were showed the presence of 673 secondary metabolites at different retention time with a range of 39 (Ta20) to 101 (Ta-12) with GC-MS. Out 673 volatile metabolites, 55 metabolites were found to be most abundant from which seven metabolites from Ta-14 and Ta-20, six metabolites from Ta-8, Ta-17 and Ta-29, five metabolites from Ta-45, Ta-15, Ta-10 and Ta-12 and remaining three metabolites from Ta-2 isolate respectively. Further, the five isolates viz., Ta-2, Ta-8, Ta-10, Ta-20 and Ta-45 were used for the LC-MS and study showed the presence of nine antifungal metabolites viz., Viridin, Viridiol, Butenolides, Harzianolides, Ferulic acid, Viridiofungin A, Cyclonerodiol, Massoilactone and Gliovirin. Hence, these isolates were produced highest number of major volatile and antimicrobial compounds. Therefore, these isolates viz., Ta-45, Ta-10, Ta-20, Ta-8, and Ta-2 were considered as high potential bio-control agents against Sclerotium rolfsii pathogens.

\section{Introduction}

The worldwide 1.5 million fungal species were identified and among them around 10\% have been discovered and described. Out of $10 \%$, only $1 \%$ fungal species has been examined for secondary metabolites based on characterization (Weber et al., 2007). The Trichoderma species has various features that could helpful for researcher's community. Amidst these diverse characteristics, which involved in production of abundant secondary metabolite compounds and some compounds are known function and rest of compounds often have vague or unidentified its functions in the organism and which are significant importance to humankind in a different field such as agricultural applications, industrial and medical. The fungus produced certain volatile compounds and these volatile 
compounds are commonly used as antibiotic as well as immunosuppressant activities (Srinivasa et al., 2014).

Trichoderma viride is the most widely used as a fungal an atagonist not only in India and other countries also. The most of $T$. Viride isolates have been submitted in gene bank; from which India are actually known as Trichoderma asperellum or its cryptic species (T. asperelloides). Sriram et al., 2013, characterized Trichoderma spp. by morphologically and also amplified the ITS and tef1 regions using oligonucleotide barcode. Antibiosis is a key role for antagonistic interactions amid micro-organisms and with adequate production of antibiotic (by Trichoderma spp.), could be utilized as biological control agents against several plant-pathogenic fungi (Weindling et al., 1936). Though, the role of antibiosis in biocontrol needs to be intensely explored, because of huge number of Trichoderma species and its strains could yield large number of antibiotics as well as secondary metabolite compounds. The fungus has a potentiality to produce volatile compounds such as, ethylene, hydrogen cyanide, alcohols and ketones and non-volatile compounds like peptides; hence these compounds are effectively inhibit the mycelial growth of disease causing fungi. Therefore, the Trichoderma spp. has an ecological advantage in soil and the rhizosphere of cultivated crop plants as well a strees spp. (Harman et al., 2004; Schnurer et al., 1999).

The Trichoderma spp has produced various volatile compounds and which are physiologically active; hence, these compounds were involved in signaling transduction in the microbial kingdom. Galindo et al., 2004, well-described 6-pentyla-pyrone (6-PAP) as a volatile product of secondary metabolism and this compounds act as herbicide and antimicrobial. In addition to, Combet et al., 2006, was reported, eight carbon volatile compounds such as 1-octen-3ol, 3-octanone, 3-octanol and 1-octen-3-one and these compounds are typical mushroom components and they play important role such as insect attractants, exhibit fungi-static and fungicidal effects (Chitarra et al., 2004; 2005; Okull et al., 2003).

Sclerotium rolfsii is a one of the highly destructive soil borne plant pathogen and which causes destructive diseases in more than 500 plant species. Hagan (1999) reported that, $S$. rolfsii as well as root knot nematode were caused exceedingly damages in southern USA. This fungus causes diseases in many crops viz., tomato, cucumber, brinjal, soybean, maize, groundnut, bean, watermelon, etc. this fungus causes various types of diseases viz., collar rot, sclerotium wilt, stem rot, charcoal rot, seedling blight, damping-off, foot-rot, stem blight and root-rot in various economically valued crops (Dwivedi et al., 2016).

The advent of molecular biology era would support in the identification of known as well as unknown secondary metabolite compounds. The Gas Chromatographic (GC)Mass Spectrometric (MS) and Liquid Chromatographic (LC)-Mass Spectrometric (MS) methods are recent and extensively used techniques for the analysis of volatile and also antifungal compounds in biological systems (Namera et al., 1999; Ramos et al., 1999; Tarbin et al., 1999; Mohamed et al., 1999; Pichini et al., 1999). These methods have been involved different mechanisms or process such as extraction, separation, purification and characterization of any compounds.

Metabolomic approach in the present study revealed the metabolites profile to understand its bio-control, biomass degradation and human pathogenicity potentiality of the $T$. 
asperellum isolates present in India. A total of 10potential isolates of $T$. asperellum were selected based on its bio-efficacy and were further characterized for secondary metabolites through GC-MS and LC-MS analysis techniques to establish valid correlation between the production of antifungal metabolites and their bio-efficacy as BCAs.

\section{Materials and Methods}

\section{Bio-efficacy of Trichoderma asperellum isolates against Sclerotium rolfsii}

10 isolates of Trichoderma asperellum were procured from Indian Institute of Horticultural Research (IIHR), Bengaluru (Table 1) and these potential isolates were tested for their bio-efficacy in in-vitrocondition against Sclerotium rolfsii at IARI, New Delhi.

\section{Dual culture method}

The isolates (Trichoderma) and test fungus (Sclerotium rolfsii) were grown on potato dextrose agar (PDA) @ 28 $\pm 20{ }^{0} \mathrm{C}$ for a week. The target fungus and Trichoderma mycelium were cut from its periphery with $5 \mathrm{~mm}$ disc and transferred to sterilized petri plates which encompass PDA media. Each plate consists of two discs, one from Trichoderma and other from test pathogen and both the discs were placed $7 \mathrm{~cm}$ away from each other. All the plate kept for incubation @ 28 $\pm 20{ }^{0} \mathrm{C}$ and observed growth of antagonist and test fungus (after eight days). The index of antagonism as percent mycelium growth inhibition of test pathogens was calculated as per ref.

\section{Characterization of secondary metabolites of $T$. asperellum isolates}

A total of 10 isolates of $T$. asperellum were used for characterization of secondary metabolites with recent and widely used GCMS and LC-MS techniques.

\section{Cultivation of isolates}

The potential bio-control $T$. asperellum isolates obtained from the earlier studies were grew for 5 days on PDA media at $30 \pm 2^{0} \mathrm{C}$. The isolates mycelium (5mm in diameter) was inoculated in a flask containing $250 \mathrm{ml}$ of potato dextrose broth (PDB). The flask mouth was plugged using cotton wool, wrapped and sealed using aluminum foil and Para film respectively. The flasks were incubated @ $30 \pm 2^{0} \mathrm{C}$ (12h darkness, 12h light) on rotary shaker for 21 days @120 rpm.

\section{Extraction and separation of antifungal} metabolites

The culture filtrate of $T$. asperellum was obtained by straining through the muslin cloth. A $225 \mathrm{ml}$ aliquot of ethyl acetate added into inoculums cultured in a $1000 \mathrm{ml}$ Erlenmeyer flask and the flask was kept overnight to ensure that the fungal cell died. Next day, culture filtrate was filtrated using Buchner vacuum funnel and filtrated culture was collected along with ethyl acetate phase, water phase and rest of cell debris (mycelium) was thrown away.

The ethyl acetate phase and with other polar constituents were separated from the water phase (medium) with the help of Buchner vacuum separation funnel and along with the sodium sulphate salt. The water phase was evaporated using rotary evaporated shaker @ $40^{\circ}$ C. immediately after evaporation; the polar constituents were collected in ethyl acetate extract. The extracted solvents were diluted in $100 \mathrm{ml}$ of $\mathrm{n}$-hexane to remove fatty acids and other non-polar elements, and then prepared 1000ppm extracted compounds with hexane solvent ( $\mathrm{n}-$ hexane extract). The acetonitrile layer of the culture filtrate was used to perform GC-MS and LC-MS analysis immediately or it can be stored in the deep freezer at $-20^{\circ} \mathrm{C}$. 


\section{Isolation of volatile compounds from isolates}

Isolation of volatile compounds was performed (Yang et al., 2009) with some modifications. The SPME fibre coated with carboxan-polydimethyl siloxanedivinylbenzene (50/60 $\mu \mathrm{m}, \mathrm{CAR} / \mathrm{PDMS} / \mathrm{DVB}$; Supelco, Bellefonte, PA, USA), used for the analysis, because of its high sensitivity towards aroma compounds and excellently reproducible. The $1 \mathrm{~g}$ each $T$. asperellum isolate was homogenized with $100 \mathrm{ml}$ double distilled water using a commercial blender. The slurry was transferred to a $250 \mathrm{ml}$ conical flask and $5 \mathrm{~g}$ of $\mathrm{NaCl}$ was added. Subsequently, the flask was sealed with a teflon-lined septum and the samples were kept stirred @ $37 \pm 1^{\circ} \mathrm{C}$. After 20 min of equilibration between the solution and the headspace, the fibre was exposed to the headspace of sealed flask for $60 \mathrm{~min}$. prior to sampling. Further, the fibre was preconditioned for $1 \mathrm{hr} @ 260^{\circ} \mathrm{C}$ in the $\mathrm{GC}$ injection port as per instructions of the manufacturer's.

\section{Gas chromatography}

Gas chromatography GC-FID analysis was carried out by a Varian-3800 gas chromatograph system with SPME sleeve adapted to injector on a VF-5 column (Varian, USA), $30 \mathrm{~m} \times 0.25 \mathrm{~mm}$ i.d, and $0.25 \mu \mathrm{m}$ film thicknesses. The helium gas was used as a

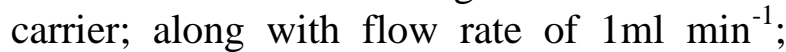
injector $250{ }^{\circ} \mathrm{C}$ and detector $260^{\circ} \mathrm{C}$ temperatures. The column temperature for program as follows: The $40{ }^{\circ} \mathrm{C}$ for 4 min was initial oven temperature and time, subsequently it was increased $3{ }^{\circ} \mathrm{C} / \mathrm{min}$ up to $180{ }^{\circ} \mathrm{C}$, held for $2 \mathrm{~min}$, further the temperature has increased at $5{ }^{\circ} \mathrm{C} / \mathrm{min}$ until it reach to $230{ }^{\circ} \mathrm{C}$ and maintained constant time for $5 \mathrm{~min}$. For desorption, the SPME device was introduced in the injector port for chromatographic analysis and remained in the inlet for $15 \mathrm{~min}$. Initially injection mode was split-less and then, split mode (1:5) after 1.5 minutes. For the qualitative identification of volatile substances and computation of retention time and index, the following standards, ethyl acetate, propanol, isobutanol, hexanol, 1-octene-3-ol and eugenol were cochromatographed.

\section{GC-MS techniques}

The Varian-3800 gas chromatograph coupled with Varian 4000 GC-MS/MS mass selective detector was used to perform GC-MS analysis. The VF-5MS (Varian, USA), column (30 m x $0.25 \mathrm{~mm}$ ID with $0.25 \mu \mathrm{m}$ film thickness) were used for separation of volatile compounds by applying the same temperature programme as mentioned in GCFID analysis. The Mass detector was used for separation of volatile compounds and this mass detector conditions were: EI-mode at 70 $\mathrm{eV}$, injector, $250{ }^{\circ} \mathrm{C}$; ion source, $220^{\circ} \mathrm{C}$; trap, $200{ }^{\circ} \mathrm{C}$; transfer line, $250{ }^{\circ} \mathrm{C}$ and full scan range, 50-450 amu. The helium gas (carrier gas) and a flow rate of 1 ml.min-1. 2.5 were used for the identification of components of the volatile compounds. The identified volatile compounds were compared with the mass spectra and the data system libraries (Wiley-2009 and NIST-2007).

\section{LC-MS techniques}

LC-MS parameters i.e. Ultra Performance Liquid Chromatography (UPLC) was performed on an Acquity H-Class ${ }^{\circledR}$ UPLC system (Waters Corporation, Milford, USA);equipped with a quaternary solvent manager, an auto-sampler maintained at $4^{\circ} \mathrm{C}$, a waters AccQ-TagTM Ultra column $(5 \mathrm{~mm} \times$ $1.2 \mathrm{~mm}, 0.2 \mu \mathrm{m}$ particles) with a pre-filter heated at $55^{\circ} \mathrm{C}$, and which coupled with a tandem quadrupole detector. The two 
different solvents were used: Solvent A: Methyl alcohol (MeOH): Water: Acetic acid (HAc) with a ratio of 80:19:1 whereas, solvent $\mathrm{B}$ : Methyl alcohol $(\mathrm{MeOH})$ and with gradient flow (2C), A: B 0' (80: 15), 0.5'(80: 15), 10'(60:40), 10.5'(60:40), 14'(80:15), 15' (80:15).The nonlinear separation gradient was used (21). The mobile phase flow rate of 0.15 $\mathrm{ml} / \mathrm{min}$, One microliter of sample was injected in duplicate into the UPLC system.

ESI-MS/MS and UPLC-MS/MS analysis were carried out on a Xevo TQD® (Waters Corporation, Milford, USA). In this investigation the parameters used for detection was followed ref. The ESI source was operated at $135^{\circ} \mathrm{C}$ with a desolvatation temperature of $350^{\circ} \mathrm{C}$, a $650 \mathrm{~L} / \mathrm{h}$ desolvatation gas flow rate and a capillary voltage was set $3.5 \mathrm{kV}$. The extractor voltage was set $3.2 \mathrm{~V}$, and the radio frequency voltage was set $3 \mathrm{~V}$. The collision gas was used as Argon whereas, collision energies varied with $19 \mathrm{eV}$ to $35 \mathrm{eV}$. Integration and quantitation were performed using the software's were Waters Target Links-TM and Masslynx.

\section{Results and Discussion}

The aim of present investigation was to develop a metabolomic method and which can be utilized to identify potential $T$. asperellum isolate against soil-borne pathogens (Sclerotium rolfsii). GC-MS and LC-MS techniques were explored to identify volatile as well as antifungal compounds produced by $T$. asperellum and to develop metabolomic profiling. Isolation of volatile compounds from $T$. asperellum isolates were performed as described by ref (Yang et al., 2009), with slight modifications (under typical solvents). The GC -MS data was deconvoluted using the software's (Wiley-2009 and NIST-2007) and which measured with mass spectra to match the entries in the compound library.
In the present investigation, it was revealed that, the culture filtrate of the 10 isolates of $T$. asperellum showed the presence of 673secondary metabolites compound at different retention time viz.,Ta-2 (57), Ta-8 (68), Ta-10 (86), Ta-12 (101), Ta-14 (53), Ta15 (73), Ta-17 (71), Ta-20 (39), Ta-29 (61) and Ta-45 (64) by GC-MS (Table 2). The volatile compounds were detected in the culture samples and which constitute members of the different compounds and with various classes such as alkanes, alcohols, ketones, pyrones (lactones), fatty acids, benzene derivatives including cyclohexane, cyclopentane, simple aromatic metabolites, terpenes, isocyano metabolites, some polyketides, butenolides and pyronesfuranes, monoterpenes, and sesquiterpenes, for which these compounds were fungal origin and which was previously reviewed by ref. (Magan et al., 2000). T. asperellum was produced high percent abundance compounds and numerous minor peaks of secondary metabolites produced by fungus. The identified metabolites and compositions of compounds were presented in table 3 and figure 1. Among the identified compounds, the most abundant compounds such as 6Pentyl-2H-Pyran-2-One (22.04\%), 2,3,5,5,8apentamethyl-6,7,8,8a-tetrahydro-5H-Chromen8-ol (15.85\%) from Ta-2 isolate, whereas Toluene (26.24\%), 2,4, Ditert-butyl phenol $(14.48 \%)$ and 6-Pentyl-2H-Pyran-2-One (27.52\%) from Ta-8 isolate, 1,5, Dimethyl-6methylene spiro $(2,4)$ heptanes and 2,4, Ditert-butyl phenol (17.00\%) from Ta-10, 1, 5, Dimethyl-1-methylenespiro $(2,4)$ heptanes (17.50\%) and N,N-Dimethyl-1-(4methylphenyl) ethanamine $(24.11 \%)$ from Ta12, Benzenethanol (39.06\%) from Ta-14, Toluene (22.38), 1,5-Dimethyl-6methylenespiro (2.4) and heptanes (13.03) from Ta-15. 6-Pentyl-2H-Pyran-2-One (21.81\%) from Ta-17. Anethanol (19.55\%) and 1-Hydroxy-2,4-di.tert butyl benzene (16.68\%) from Ta-29, 1,5, Dimethyl-6- 
methylene spiro $(2,4)$,heptanes $(16.93 \%)$, PPropenyl phenyl methyl ether $(20.31 \%)$ and 2,4-Di-tert-butyl phenol (19.77\%) from Ta45, and Epizonarene (29.71\%), 2,5-Di-tertbuytlphenol (10.04\%) and 2,3,5,5,8apentamethyl-;7,8,8,8A-tetra hydro-5Hchromen-8-ol (16.43\%) from Ta-20. Only few compounds were innovative and rest of compounds was previously known. Amidst compounds, the most abundant metabolite identified in this study was 6-pentyl-alphapyrone (6-PP) followed by Toluene, Azulene and Anethol.

The compound, 6-PP was reported and characterized by Collins and Halim, 1972(23), and they identified as one of the key bioactive compounds of several isolates, e.g., $T$. asperellum has reviewed by $(24,25,2)$. The most important volatile compound was obtained from pyrone (peak 13 from Ta-2, peak 63 from Ta-12, peak-36 from Ta-17, peak 14 from Ta-20 and peak 42 from Ta-45 respectively).This compound is oxygen heterocyclic compound and dehydroderivative showing characteristics of coconut odour and which is the peculiar characteristic to identify the T. asperellum (earlier T. viride).

This is a nontoxic flavoring agent and which was chemically synthesized for industrial purposes before its discovery as a natural product and which was involved in cellular function, plant growth regulation, plant defense response and antifungal activity (ElHassan et al., 2009; Reino et al., 2008; Siddiquee et al., 2012). The metabolomic profiling was done using 21 days old culture filtrate of five potential isolates of $T$. asperellum viz., Ta-2, Ta- 8, Ta- 10, Ta- 20 and Ta-45 were selected for further analysis with LC-MS techniques based on their bio-efficacy test using dual culture method. The study revealed that, the Ta-45 isolates showed highest percent inhibition up to $80.04 \%$ followed by Ta-10 (74.56\%), Ta-20 (73.79\%) and Ta-8 (70.26\%). The Ta-2 isolate (58.13\%) showed lowest percent inhibition among 10 isolates of $T$. asperellum and to establish valid correlation between the production of antifungal metabolites and their efficacy as BCAs (Fig.2.1 and 2.2).

Further, preliminary experiment was performed to optimization of extraction yield and LC-MS chromatographic profiling. ESIMS/MS spectrum of Ta-2 isolate showed four prominent peaks correspondingly four compounds were tentatively identified as Butenolides $\left(\mathrm{C}_{4} \mathrm{H}_{4} \mathrm{O}_{2}\right)$ with the molecular ion peak exhibited at $243.3 \mathrm{~m} / \mathrm{z}$, Cyclonerodiol $\left(\mathrm{C}_{15} \mathrm{H}_{28} \mathrm{O}_{2}\right)$ with peak mass exhibited at $241.38 \mathrm{~m} / \mathrm{z}$, Ferulic acid $\left(\mathrm{C}_{10} \mathrm{H}_{10} \mathrm{O}_{4}\right)$ with molecular ions at $195.18 \mathrm{~m} / \mathrm{z}$ and Gliovirin $\left(\mathrm{C}_{20} \mathrm{H}_{20} \mathrm{~N}_{2} \mathrm{O}_{8} \mathrm{~S}_{2}\right)$ with peak mass exhibited at $481.5 \mathrm{~m} / \mathrm{z}$.

Similarly, the spectrum of Ta- 8 isolate showed 6 peaks correspondingly six compounds were tentatively identified as Ferulic acid $\left(\mathrm{C}_{10} \mathrm{H}_{10} \mathrm{O}_{4}\right)$ with molecular ions at $195.18 \mathrm{~m} / \mathrm{z}$, Harzianolides $\left(\mathrm{C}_{13} \mathrm{H}_{18} \mathrm{O}_{3}\right)$ with molecular ions at $223.28 \mathrm{~m} / \mathrm{z}$, Cyclonerodiol $\left(\mathrm{C}_{15} \mathrm{H}_{28} \mathrm{O}_{2}\right)$ with peak mass exhibited at $241.38 \mathrm{~m} / \mathrm{z}$, Viridin $\left(\mathrm{C}_{20} \mathrm{H}_{16} \mathrm{O}_{6}\right)$ with molecular ions at $353.09 \mathrm{~m} / \mathrm{z}$, Gliovirin $\left(\mathrm{C}_{20} \mathrm{H}_{20} \mathrm{~N}_{2} \mathrm{O}_{8} \mathrm{~S}_{2}\right)$ with peak mass exhibited at $481.5 \mathrm{~m} / \mathrm{z}$ and Mass oil actone $\left(\mathrm{C}_{10} \mathrm{H}_{16} \mathrm{O}_{2}\right)$ with molecular ions at $169.232 \mathrm{~m} / \mathrm{z}$.

The spectrum of Ta-10 isolate showed five prominent peaks correspondingly five compounds were tentatively identified as Ferulic acid $\left(\mathrm{C}_{10} \mathrm{H}_{10} \mathrm{O}_{4}\right)$ with molecular ions at $195.18 \mathrm{~m} / \mathrm{z}$, Viridin $\left(\mathrm{C}_{20} \mathrm{H}_{16} \mathrm{O}_{6}\right)$ with molecular ions at $353.09 \mathrm{~m} / \mathrm{z}$, Viridiol $\left(\mathrm{C}_{20} \mathrm{H}_{18} \mathrm{O}_{6}\right)$ with molecular ions at 355.35 $\mathrm{m} / \mathrm{z}$, Gliovirin $\left(\mathrm{C}_{20} \mathrm{H}_{20} \mathrm{~N}_{2} \mathrm{O}_{8} \mathrm{~S}_{2}\right)$ with peak mass exhibited at $481.5 \mathrm{~m} / \mathrm{z}$ and Viridiofungin $\mathrm{A}$ $\left(\mathrm{C}_{31} \mathrm{H}_{45} \mathrm{NO}_{10}\right)$ with peak mass exhibited at $562.7 \mathrm{~m} / \mathrm{z}$. 
Table.1 Details of the T.asperellum isolates used for present study

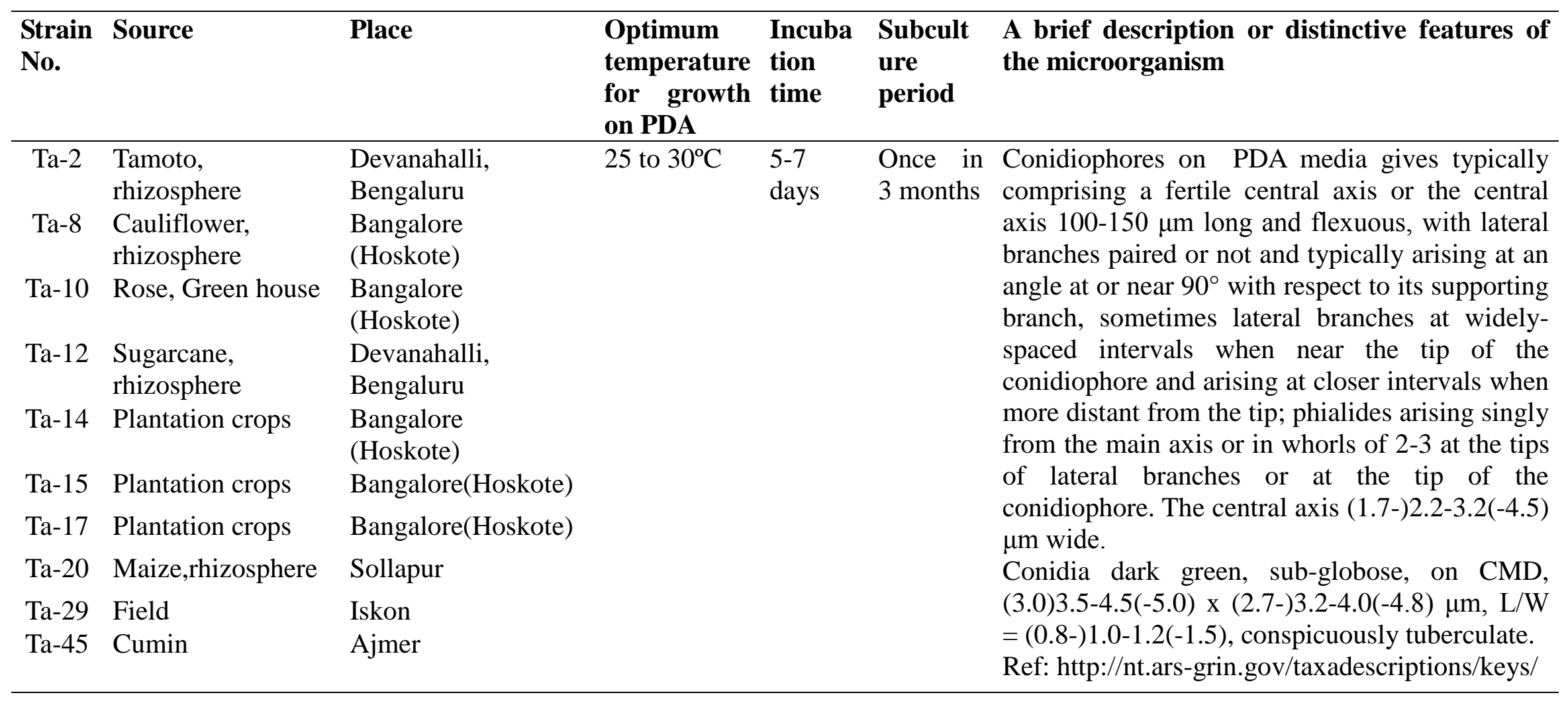


Table.2 List of total number of Volatile metabolites produced from the T.asperellum isolates

\begin{tabular}{ccc}
\hline Sl. No. & Isolates & Volatile compounds \\
\hline 1 & Ta-2 & 57 \\
2 & Ta-8 & 68 \\
3 & Ta-10 & 86 \\
4 & Ta-12 & 101 \\
5 & Ta-14 & 53 \\
6 & Ta-15 & 73 \\
7 & Ta-17 & 71 \\
8 & Ta-20 & 39 \\
9 & Ta-29 & 61 \\
10 & Ta-45 & 64 \\
\hline
\end{tabular}

Table.3 The most abundant volatile metabolites identified from the T.asperellum isolates using GC-MS

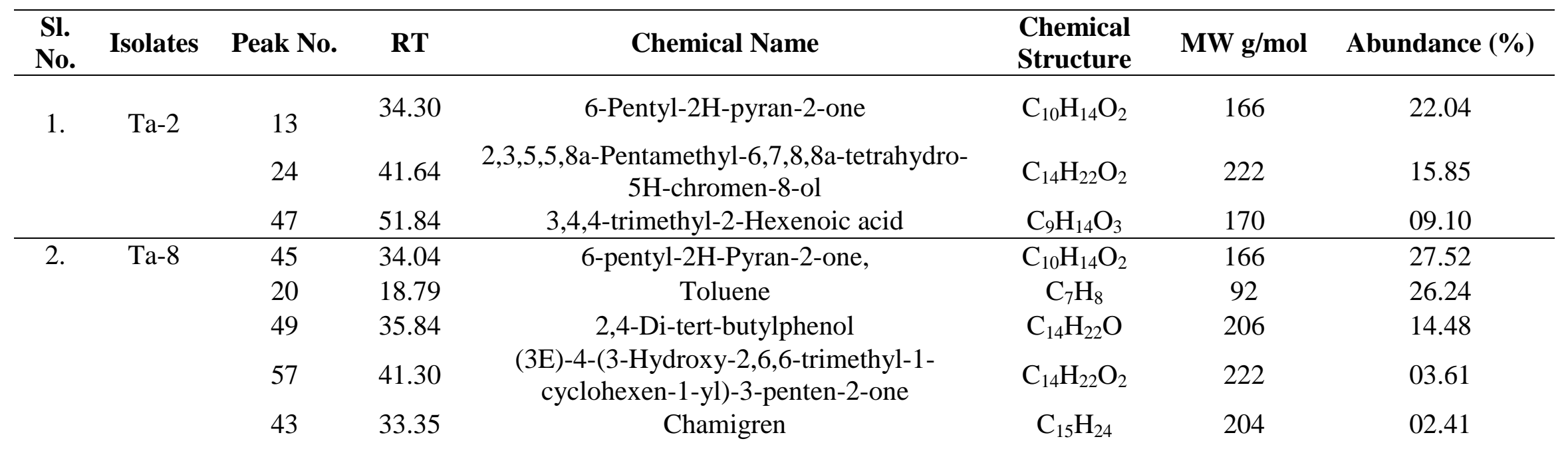


Int.J.Curr.Microbiol.App.Sci (2017) 6(5): 1105-1123

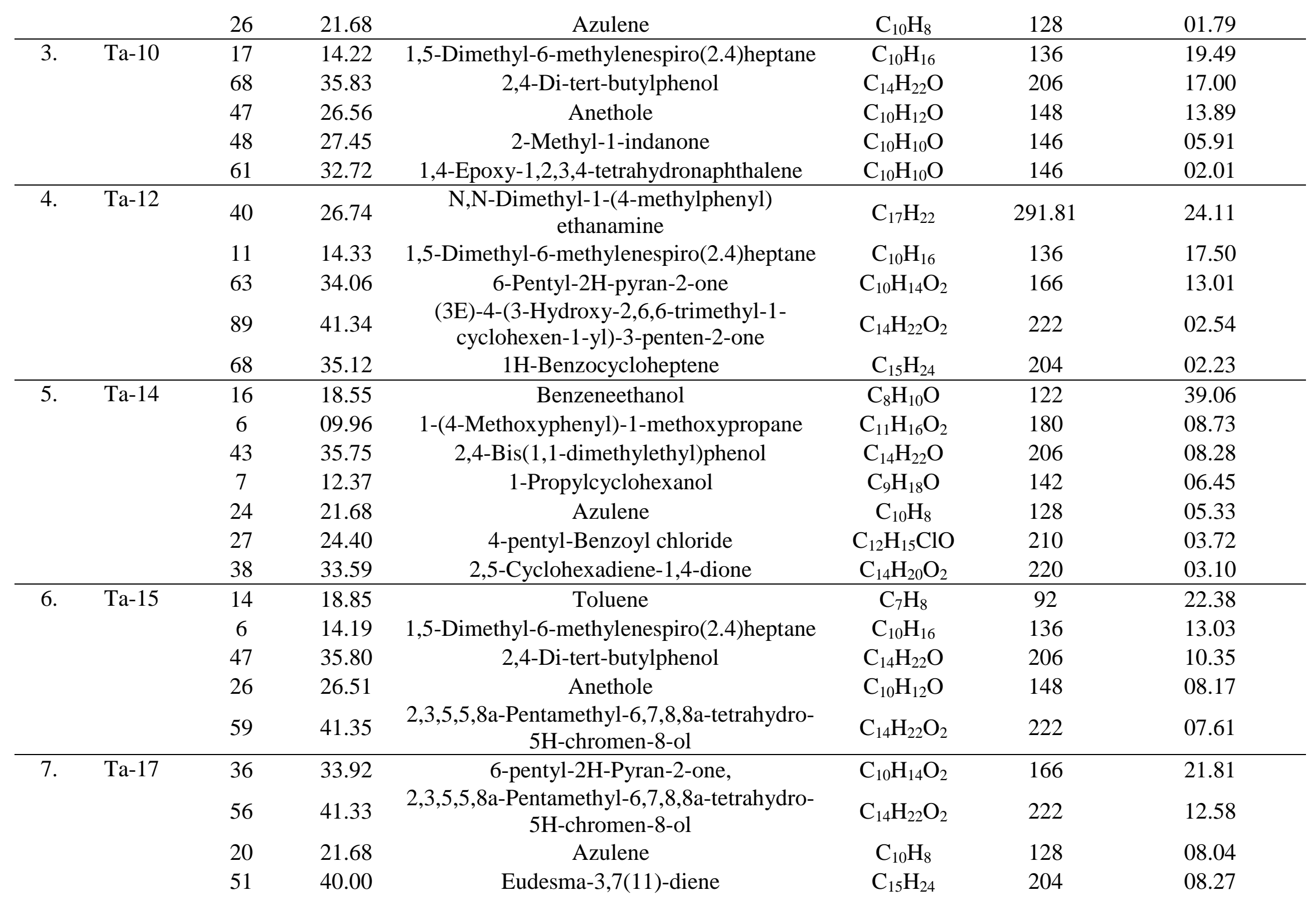




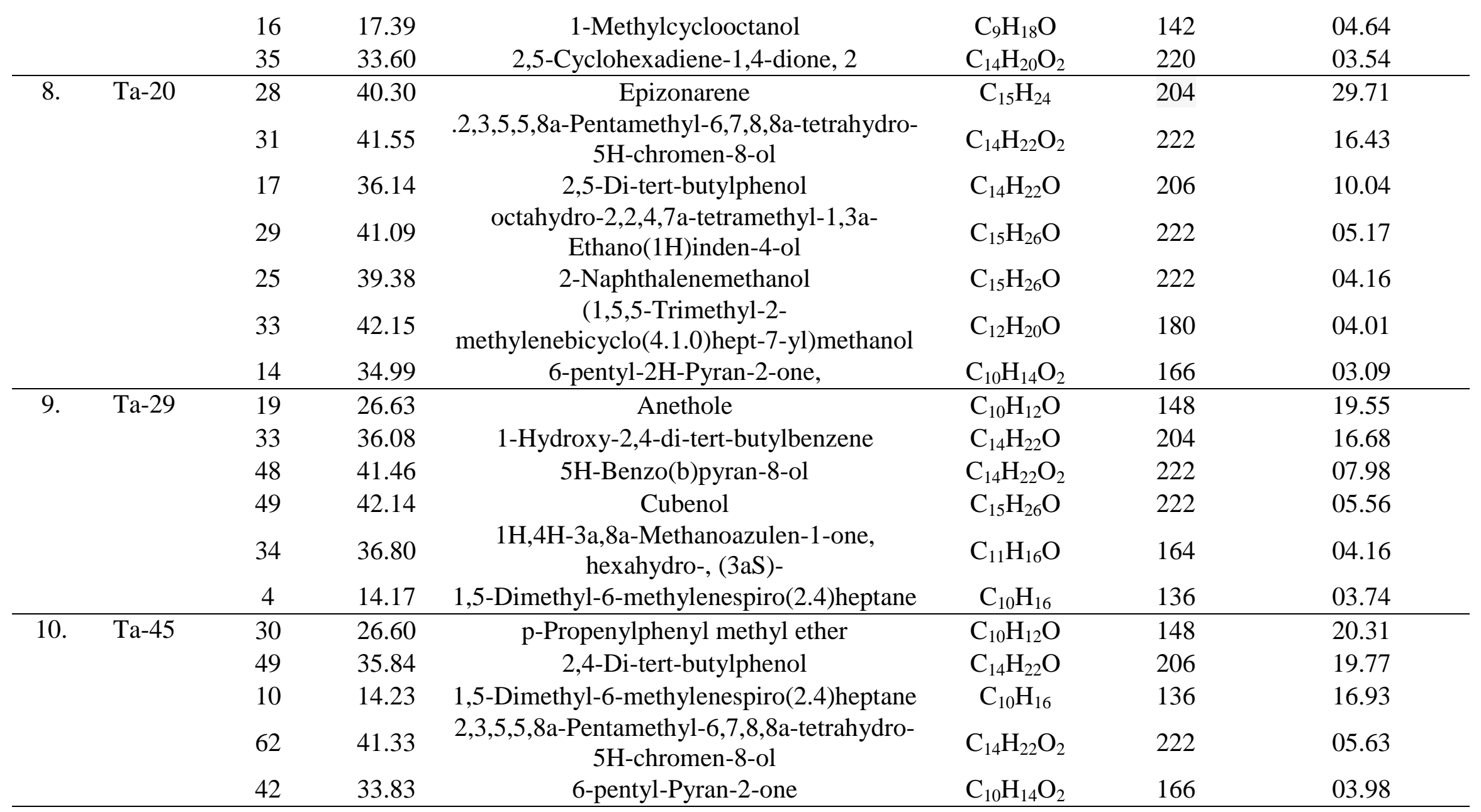


Table.4 List of antifungal compounds identified from the T.asperellum isolates using LC-MS

\begin{tabular}{|c|c|c|c|c|c|c|c|c|c|}
\hline \multirow{2}{*}{$\begin{array}{c}\text { Chemical } \\
\text { compound/Derivat } \\
\text { ives }\end{array}$} & \multirow[t]{2}{*}{ MW } & \multicolumn{5}{|c|}{$\begin{array}{c}\text { Relative Abundance \% (TIC) } \\
\text { Total Ion Current }\end{array}$} & \multirow[t]{2}{*}{$\begin{array}{l}\text { Antibiotic } \\
\text { activity }\end{array}$} & \multirow[t]{2}{*}{ References } & \multirow[t]{2}{*}{ Biological functions } \\
\hline & & Ta-2 & Ta-8 & Ta-10 & Ta-20 & Ta-45 & & & \\
\hline $\begin{array}{l}\text { Viridin } \\
\text { (Furanosteroid) }\end{array}$ & 352.09 & 0 & 259 & 262 & 378 & 0 & Antibiotic & $(32,33)$ & $\begin{array}{l}\text { Inhibition of Fungal } \\
\text { spore } \\
\text { germination,Fungistatic, } \\
\text { Anticancer }\end{array}$ \\
\hline $\begin{array}{l}\text { Viridiol } \\
\text { (Steroid) }\end{array}$ & 354.35 & 0 & 0 & 297 & 0 & 0 & Antifungal & $(34,35)$ & $\begin{array}{l}\text { Herbicidal property } \\
\text { Antiaging }\end{array}$ \\
\hline $\begin{array}{l}\text { Butenolides } \\
\text { (Trichothecene) }\end{array}$ & 242.30 & 155 & 0 & 0 & 234 & 0 & Antifungal & (36) & $\begin{array}{l}\text { Insecticidaland Anti- } \\
\text { bacterial activity }\end{array}$ \\
\hline $\begin{array}{l}\text { Harzianolides } \\
\text { (Diterpenes) }\end{array}$ & 222.28 & 0 & 281 & 0 & 148 & 0 & Antifungal & $(37,26)$ & Plant growth regulator \\
\hline $\begin{array}{l}\text { Ferulic acid } \\
\text { (Phenypropanoids) }\end{array}$ & 194.18 & 162 & 966 & 395 & 111 & 166 & Fungicide & $(38,39)$ & $\begin{array}{l}\text { Antimutagenic, } \\
\text { Anti-microbial } \\
\text { antioxidant }\end{array}$ \\
\hline $\begin{array}{l}\text { Viridiofungin A } \\
\text { (Alkylcitrate) }\end{array}$ & 561.70 & 0 & 0 & 139 & 0 & 0 & Antibiotic & $(40,41,42)$ & $\begin{array}{l}\text { Fungitoxic, Antibacterial } \\
\text { Inhibition of Ergosterol } \\
\text { synthesis and Serine } \\
\text { palmitotyltransferase } \\
\text { enzyme }\end{array}$ \\
\hline $\begin{array}{l}\text { Cyclonerodiol oxide } \\
\text { (Sesquiterpenes) }\end{array}$ & 240.38 & 110 & 182 & 0 & 243 & 0 & Antifungal & $(43,44,45,46)$ & $\begin{array}{l}\text { Plant growth regulator } \\
\text { Antitumor }\end{array}$ \\
\hline $\begin{array}{l}\text { Gliovirin } \\
\text { (Alkaloides) }\end{array}$ & 480.06 & $1.28 \mathrm{e} 3$ & 300 & $1.92 \mathrm{e} 3$ & 201 & $1.12 \mathrm{e} 3$ & $\begin{array}{l}\text { Antibiotic } \\
\text { Antiviral }\end{array}$ & $(47,48)$ & $\begin{array}{l}\text { Immune } \quad \text { suppressive } \\
\text { activity, } \\
\text { activity }\end{array}$ \\
\hline $\begin{array}{l}\text { Massoilactone } \\
\text { (Pentaketides) }\end{array}$ & 168.23 & 0 & $1.24 \mathrm{e} 3$ & 0 & 612 & 0 & Antifungal & (49) & Plant growth regulator \\
\hline
\end{tabular}


Int.J.Curr.Microbiol.App.Sci (2017) 6(5): 1105-1123

Fig.1 GC-MS spectrums of the culture filtrate of Ta-14 isolates

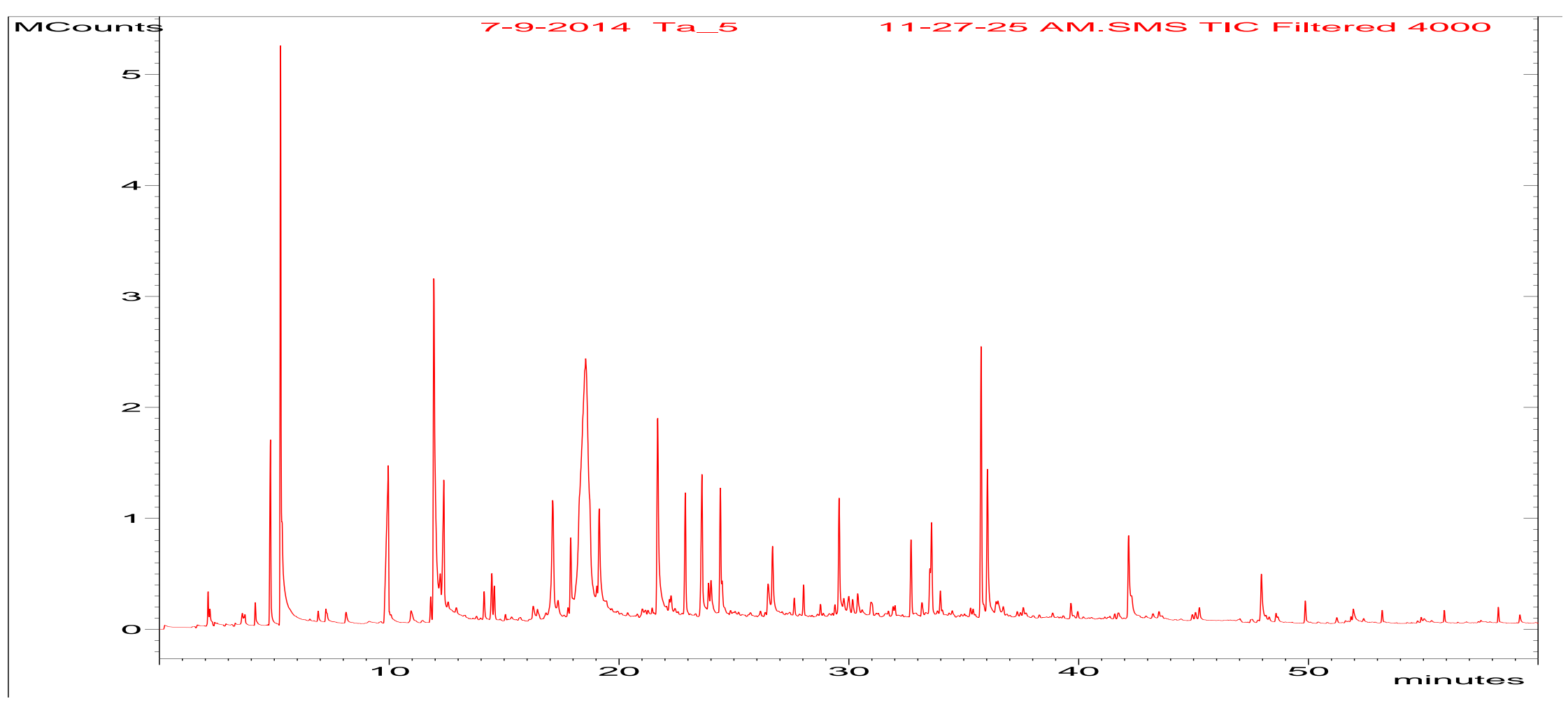

Ta-14 isolates showed seven secondary metabolites 
Fig.2.1 Bio-efficacy of $T$. asperellum isolates effective against $S$. rolfsii (Plates)

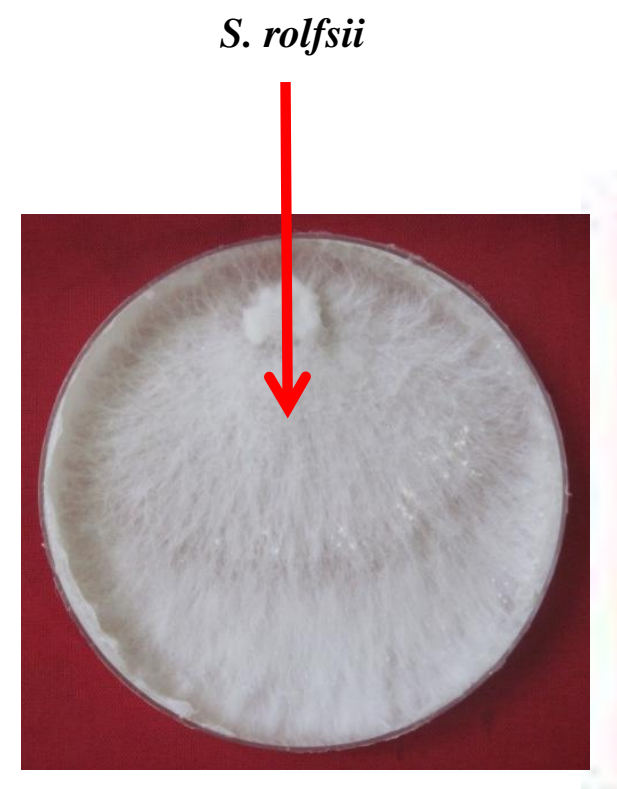

Control

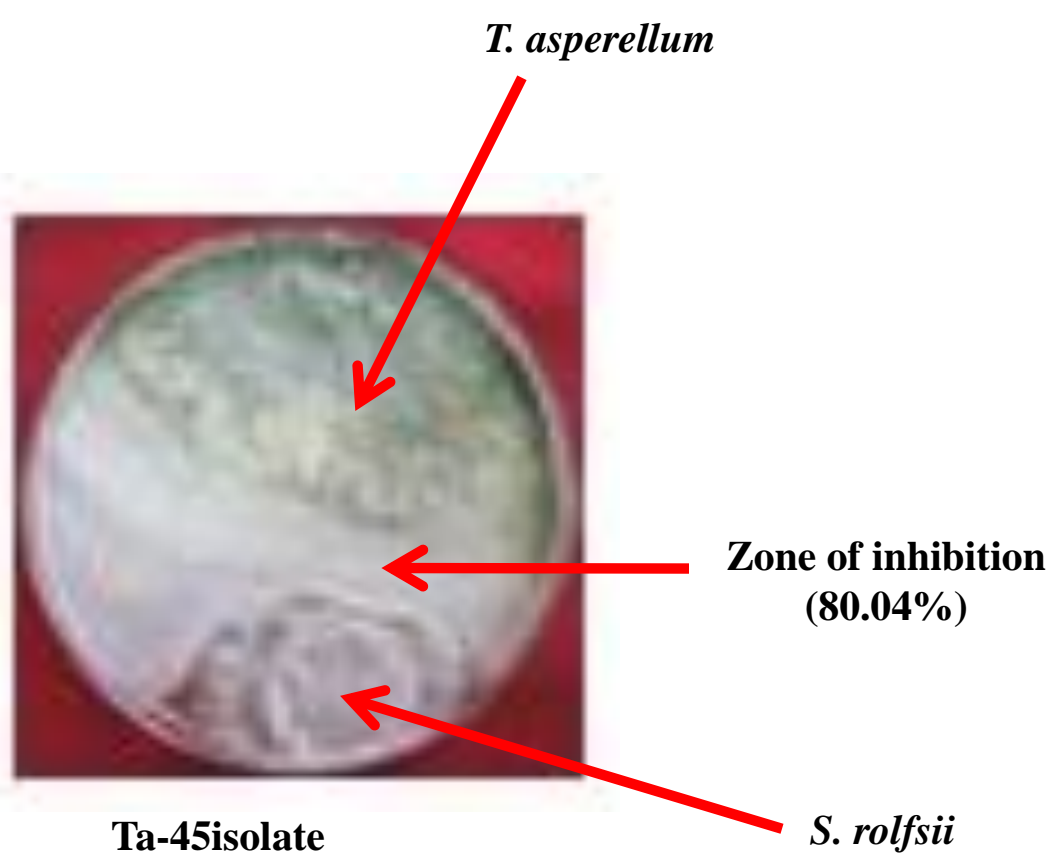

1117 
Int.J.Curr.Microbiol.App.Sci (2017) 6(5): 1105-1123

Fig.2.2 Bioefficacy of $T$. asperellum isolates effective against $S$. rolfsii

Percent Mycelial Inhibition(PMI)

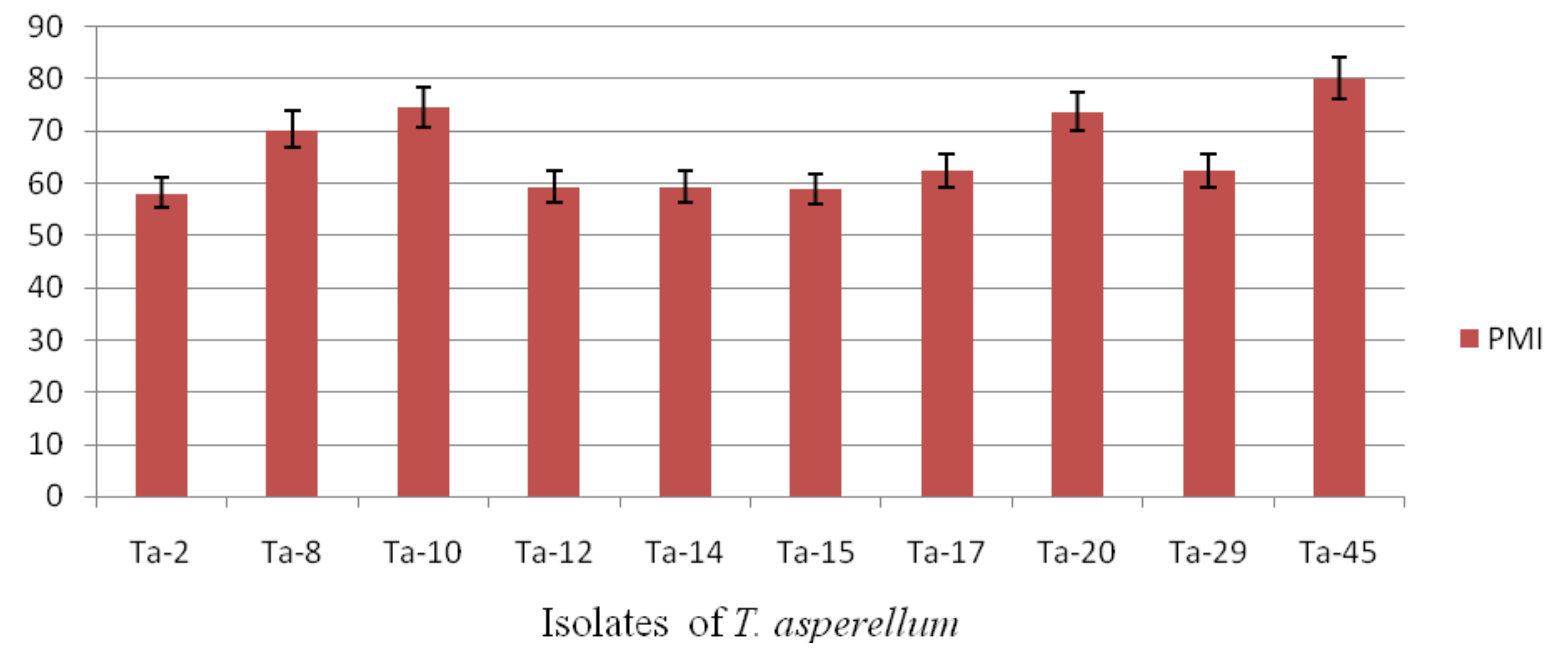

Grand Mean $=65.94, \mathrm{SEm}=0.65, \mathrm{CD}$ at $\mathbf{1 \%}=2.63, \mathrm{CD}$ at $\mathbf{5 \%}=1.92$ and $\mathrm{CV}=1.71$ 
Fig.4 Chromatogram of total ion current \& antifungal compounds of Ta-45 isolate by LC-MS

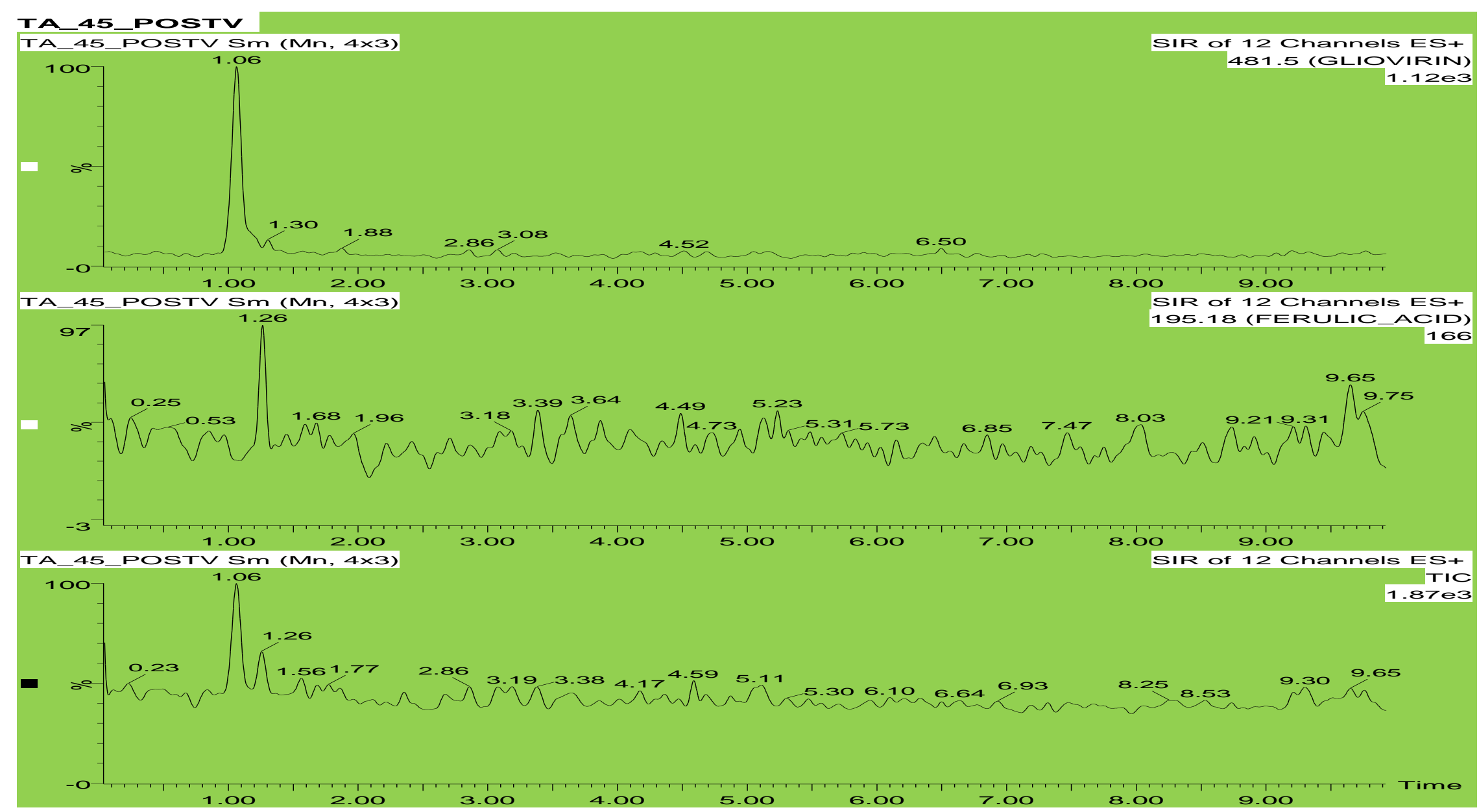

\section{Ta-45 isolate}


The spectrum of Ta-20 isolate showed seven prominent peaks correspondingly seven compounds were tentatively identified as Massoilactone $\left(\mathrm{C}_{10} \mathrm{H}_{16} \mathrm{O}_{2}\right)$ with molecular ions at $169.232 \mathrm{~m} / \mathrm{z}$, Ferulic acid $\left(\mathrm{C}_{10} \mathrm{H}_{10} \mathrm{O}_{4}\right)$ with molecular ions at $195.18 \mathrm{~m} / \mathrm{z}$, Harzianolides $\left(\mathrm{C}_{13} \mathrm{H}_{18} \mathrm{O}_{3}\right)$ with molecular ions at $223.28 \mathrm{~m} / \mathrm{z}$, Cyclonerodiol $\left(\mathrm{C}_{15} \mathrm{H}_{28} \mathrm{O}_{2}\right)$ with peak mass exhibited at $241.38 \mathrm{~m} / \mathrm{z}$, Butenolides $\left(\mathrm{C}_{4} \mathrm{H}_{4} \mathrm{O}_{2}\right)$ with the molecular ion peak exhibited at $243.3 \mathrm{~m} / \mathrm{z}$, Viridin $\left(\mathrm{C}_{20} \mathrm{H}_{16} \mathrm{O}_{6}\right)$ with molecular ions at $353.09 \mathrm{~m} / \mathrm{z}$ and Gliovirin $\left(\mathrm{C}_{20} \mathrm{H}_{20} \mathrm{~N}_{2} \mathrm{O}_{8} \mathrm{~S}_{2}\right)$ with peak mass exhibited at $481.5 \mathrm{~m} / \mathrm{z}$ (Table 4 and Fig. 3).

The LC-ESI-MS negative-ion chromatogram of $T$. asperellum isolates shows the positions of significantly different metabolites. The antifungal compounds produced by the $T$. asperellum are attributed compounds for the bioactivity and have a function as bio-control agent, which may contribute to the mitigation of the unnecessary use of chemical pesticides, easily biodegradable in the soils and reduce the environmental pollution.

Among 10 isolates of $T$. asperellum, only Ta20, Ta-10, Ta-8 and Ta-2 isolates were produced highest number of major antimicrobial compounds. Therefore, these isolates can be considered as high potential bio-control agents against Sclerotium rolfsii pathogens. This finding was agreements with the studies of Srinivasa and Prameela Devi, 2014; Siddiquee et al., 2012. From this investigation 09 major antimicrobial compounds were analyzed and this study envisages the importance of reports given by (Sivasithamparam et al., 1998; Vinale et al., 2006).

In the present study, secondary metabolites were successfully separated and identified from $T$. asperellum isolates through GC-MS and LC-MS method. Among 10 isolates, Ta20 and Ta-10 were the highest producers of secondary metabolites and which encompasses antibiotics and found to be highly significant compared to rest of isolates.

In conclusion, Trichoderma species is well known for decades, and the present investigation has been confirmed that the fungus has ability to produce abundant secondary metabolites and these metabolites were quantified in same studies with the help of recent advent techniques known as GC-MS and LCMS approach. Metabolomics is a powerful tool in system biology which allows us to gain insight into the identification of unknown and known secondary metabolites in potential isolates of $T$. asperellum which is used as most predominant and promising BCA in India for the management of soilborne pathogens (Sclerotium rolfsii). With the help of this approach 673 secondary metabolites were identified with GC-MS. Out of 673 metabolites, 55 metabolite compounds were found to be most abundant in all the isolates. Further, isolates viz., Ta-45, Ta-10, Ta-20, Ta-8, and Ta-2 with LCMS approach showed highest production of antifungal secondary metabolites. Therefore, these isolates can be used as high potential biocontrol agents against soil borne pathogens (Sclerotium rolfsii). Combination of GC-MS and LC-MS approaches would help us in identifying high potential bio-control agents against soil borne pathogens in a greater extent which could have a great potential for future application of metabolites.

\section{Acknowledgements}

The authors thankful to the Directors, IARI, New Delhi and IIHR, Bengaluru respectively and also the Head, Division of Plant Pathology, IARI, New Delhi for providing opportunity to visit IIHR, Bengaluru for the professional Attachment Training and use facilities for the study and I also thank to Dr. T. K. Roy for the skilled assistance in the analysis of samples. 


\section{References}

Abbas El-Hasan, Frank Walker, Jochen Schone and Heinrich Buchenauer. 2009. Detection of viridio-fungin $\mathrm{A}$ and other antifungal metabolites excreted by Trichodermaharzianum active against different plant pathogens. Eur. J. Plant Pathol., 124: 457-470.

Armenta, J.M., Cortes, D.F., Pisciotta, J.M., Shuman, J.L., Blakeslee, K., Rasoloson, D., Ogunbiyi O., Sullivan D.J., Jr, and Shulaev, V. 2010. Sensitive and rapid method for amino acid quantitation in malaria biological samples using AccQ. Tagultra performance liquid chromatography-electrospray ionizationMS/MS with multiple reaction monitoring. Anal Chem., 82(2): 548-558. doi: 10.1021/ac901790q.

Betina, V. 1989. Mycotoxins: Chemical, Biological and Environmental Aspects, Bioactive Molecules. Elsevier, Amsterdam.

Brian, P.W., Curtis, P.J., Howland, S.R., Jeffreys, E.G. and Raudnitz, H. 1951. Three new antibiotics from a species of Gliocladium. Experientia, 7: 266-267.

Chitarra, G.S., Abee, T., Rombouts, F.M. and Dijksterhuis, J. 2005. 1-Octen-3-olinhibits conidia germination of Penicilliumpaneum despite of mild effects on membrane permeability, respiration, intracellular $\mathrm{pH}$, and changes the protein composition; FEMS Microbiol. Ecol., 54: 67-75.

Chitarra, G.S., Abee, T., Rombouts, F.M., Posthumus, M.A. and Dijksterhuis, J. 2004. Germination of Penicilliumpaneum conidia is regulated by 1 -octen-3-ol, a volatile self-inhibitor. Appl. Environ. Microbiol., 70(5): 2823-2829.

Claydon, N., Allan, M., Itanson, J.R. and Avent, A.G. 1987. Antifungal alkyl pyrones of Trichodermaharzianum. Transactions of the British Mycological, 88: 503-513.

Collins, R.P. and Halim, A.F. 1972. Characterizations of the major aroma constituent of the fungus Trichodermavirens (Pers.). J. Agri. Food Chem., 20: 437-438.

Combet, E., Eastwood, D.C., Burton, K.S., Combet, E., Henderson, J., Henderson, J. and Combet, E. 2006. Eight-carbon volatiles in mushrooms and fungi: properties, analysis, and biosynthesis. Mycosci., 47: 317-326.

Cutler, H.G., Jacyno, J.M., Phillips, R.S., Vontursch, R.L., Cole P.D. and Montemurro, N. 1991a. Cyclonerodiol from a novel source, Trichodermakoningii: plant growth regulating activity. Agric. Biol. Chem., 55: 243-244.

Dickinson, J.M., Hanson, J.R. and Truneh, A. 1995. Metabolites of some biological control agents. Pestic Sci., 44: 389-393.

Duke, J.A. 1992. Handbook of Biologically Active Phytochemicals and their Activities. CRC Press, Boca Raton.

Dwivedi, S.K. and Ganesh Prasad. 2016. Integrated management of Sclorotiumrolfsii: An overview. European J. Biomed. Pharmaceutical Sci., 3(11): 137-146.

El-Hassan, A. and Buchennauer, H. 2009. Action of 6-penthyl-alpha pyrone in controlling seedling blight incited by Fusariummoniliforme and inducing defense responses in maize. $J$. Phytopathol., 157: 697-707.

Fujita, T., Takaishi, Y., Takeda, Y., Fujiyama, T. and Nishi, T. 1984. Fungal metabolites. II. Structural elucidation of minor metabolites, valinotricin, cyclonerodiol oxide, epicyclonerodiol oxide from Trichodermapolysporum. Chem. Pharm. Bull., 32: 4419-4425.

Galindo, E., Flores, C., Larralde-Corona, P., Corkidi-Blanco, G., Rocha-Valadez, J.A. and Serrano-Carreon, L. 2004. Production of 6-pentyl-alpha-pyrone by Trichodermaharzianum cultured in unbaffled and baffled shake flasks. Biochemical Engi. J., 18(1): 1-8.

Ghisalberti, E.L. and Rowland, C. 1993. Antifungal metabolites from 
Trichodermaharzianum. J. Nat. Prod., 56: 1799-1804.

Ghisalberti, E.L., Hockless, D.C.R., Rowland, C. and White, A.H. 1992. Harziandione, a new class of diterpene from Trichodermaharzianum. J. Nat. Prod., 55: 1690-1694.

Golder, W.S. and Watson, T.R. 1980. Lanosterol derivatives as precursors in the biosynthesis of viridin. J. Chem. Soc. Perkin Trans., 1: 422-425.

Grove, J.F.1966. The structure of gliorosein. $J$. Chem. Soc. (C)., pp-985.

Hagan, A.K.1999. Plant Dis., 3: 73-75.

Hanssen, H.P. and Urbasch, I. 1990. 6-Pentylalpha-pyrone. A fungicidal metabolic product of Trichoderma spp. (Deuteromycotina). Proceedings of the Fourth Int. Mycol. Congress, Regensburg, Germany., pp-260.

Harman, G.E., Howell, C.R., Viterbo, A., Chet, I. and Lorito, $\mathrm{M}$. 2004.Trichodermaspecies-

Opportunistic, avirulent plant symbionts. Nature Reviews Microbiol., 2: 43-56.

Hill, R.A., Cutler, H.G. and Parker, S.R. 1995. Trichoderma and metabolites as control agents for microbial plant diseases. PCT Int. Appl., WO 20,879 (Chem. Abstr. 123: 220823).

Howell, C.R. and Stipanovic, R.D. 1983. Gliovirin, a new antibiotic from Gliocladiumvirens and its role in the biological control of Pythiumultimum. Can. J. Microbiol., 29: 321-324.

Huang, Q., Tezuka, Y., Hatanaka, Y., Kikuchi, T., Nishi, A. and Tubaki, K.1995a. Studies on metabolites of mycoparasitic fungi. III. New sesquiterpene alcohol from Trichodermakoningii. Chem. Pharm. Bull., 43: 1035-1038.

Lumsden, R.D., Ridout, C.J., Vendemia, M.E., Harrison, D.J., Waters, R.M. and Walter, J.F. 1992b. Characterization of major secondary metabolites produced in soilless mix by a formulated strain of the biocontrol fungus Gliocladiumvirens. Can. J. Microbiol., 38: 1274-1280.
Magan, N. and Evans, P. 2000. Volatiles as an indicator of fungal activity and differentiation between species, and the potential use of electronic nose technology for early detection of grain spoilage. J. Stored Products Res., 36: 319-340.

Moffatt, J.S., Bu'lock, J.D. and Yuen, T.H. 1969. Viridiol, a steroid-like product from Trichoderma viride. J. Chem. Soc. Chem. Commun., Pp-839.

Mohamed, S.S., Khalid, S.A., Ward, S.A.M., Wan, T.S., Tang, H.P.O., Zheng, M., Haynes, R.K. and Edwards, G.E. 1999. Simultaneous determination of artemether and its major metabolite dihydroartemisinin in plasma by gas chromatography-mass spectrometryselected ion monitoring. J. Chromatogr. B., 731: 251-60.

Morton, D.T. and Stroube, N.H. 1955. Antagonistic and stimulatory effect of microorganism upon Sclerotium rolfsii. Phytopathol., 45: 419-420.

Namera, T., Watanabe, M., Yashiki, T., Kojima, and Urabe, T. 1999. Simple and sensitive analysis of nereistoxin and its metabolites in human serum using headspace solidphase micro-extraction and gas chromatography-mass spectrometry. $J$. Chromatogr. Sci., 37(3): 77-82.

Okull, D.O., Beelman, R.B. and Gourama, H. 2003. Antifungal activity of 10-oxo-trans8-decenoic acid and 1-octen-3-ol against Penicilliumexpansum in potato dextrose agar medium. J. Food Protection, 66(8): 1503-1505.

Pichini, S., Pacifici, R., Altieri, I., Pellegrini, M. and Zuccaro, P. 1999. Determination of lorazepam in plasma and urine as trimethylsilyl derivative using gas chromatography-tandem mass spectrometry. J. Chromatogr. B., 732: 509-14.

Ramos, F., Matos, A., Oliviera, A. and Noronka, da Silveira, M.I. 1999. Diphasic dialysis extraction technique for clenbuterol determination in bovine retina by gas chromatography-mass 
spectrometry. Chromatographia, 50: 118-20.

Reino J.L., Guerriero R.F., Herna`ndez-Gala R. and Collado, I.G. 2008. Secondary metabolites from species of the biocontrol agent Trichoderma. Phytochem. Rev., 7: 89-123.

Rukmini, C., and Bhat, R.V. 1978. Occurrence of T-2 toxin in Fusarium-infested sorghum from India. J. agric. Food Chem., 26: 647-649.

Schnurer, J., Olsson, J. and Borjesson, T. 1999. Fungal volatiles as indicators of food and feeds spoilage. Fungal Genetics and Biol., 27: 209-217.

Siddiquee, S., Bo Eng Cheong., Khanam Taslima, Hossain Kausar and Md Mainul Hasan. 2012. Separation and Identification of Volatile Compounds from Liquid Cultures of Trichodermaharzianum by GC-MS using Three Different Capillary Columns. J. Chromatographic Sci., 50: 358-367.

Sivasithamparam, K. and Ghisalberti, E.L. 1998. Trichoderma and gliocladium. Kubicek, C.P., Harman, G.E. (eds), Vol. 1. Taylor \& Francis Ltd., London, pp139-188.

Srinivasa, N. and Prameela Devi, T. 2014. Separation and identification of antifungal compounds from Trichoderma species by GC-MS and their bio-efficacy against soil-borne pathogens. Bioinfolet., 11(1B): 255-257.

Sriram, S., Savitha, M.J., Rohini, H.S. and Jalali, S.K. 2013. The most widely used fungal antagonist for plant disease management in India, Trichoderma viride is Trichoderma asperellum as confirmed by oligonucleotide barcode and morphological characters. Curr. Sci., 104: 1332-1340.

Tarbin J.A. Clarke P. and Shearer G. 1999. Screening of sulphonamides in egg using gas-chromatography-mass selective detection and liquid chromatographymass spectrometry. J. Chromatogr., B 729: 127-38.

Turner, W.B. and Aldridge, D.C. 1983. Fungal Metabolites II. Academic Press, London.

Vinale, F., Marra, R., Scala, F., Ghisalberti, E.L., Lorito, M. and Sivasithamparam, K. 2006. Major secondary metabolites produced by two commercial Trichoderma strains active against different phytopathogens. Lett. Appl. Microbiol., 43: 143-8.

Vinale, F., Sivasithamparam, K., Ghisalberti, E.L., Marra, R., Barbetti, M.J. and Li, H., et al. 2008. A novel role for Trichodermasecondary metabolites in the interactions with plants. Physiol. Mol. Plant Pathol., 72: 80-86.

Weber, R.W.S., Kappe, R., Paululat, T., Mosker, E. and Anke, H. 2007. AntiCandida metabolites from endo-phytic fungi. Phytochem., 68: 886-892.

Weindling, R. and Emerson, H. 1936. The isolation of a toxic substance from the culture filtrates of Trichoderma. Phytopath., 26: 1068-1070.

Yang, C., Wang, Y., Liang, Z., Fan, P., Wu, B., Yang, L., Wang, Y. and Li, S. 2009. Volatiles of grape berries evaluated at the germplasm level by headspaceSPME with GC-MS. Food Chem., 114: 1106-1114.

\section{How to cite this article:}

Srinivasa, N., S. Sriram, Chandu Singh and Shivashankar, K.S. 2017. Secondary Metabolites Approach to Study the Bio-Efficacy of Trichoderma asperellum Isolates in India. Int.J.Curr.Microbiol.App.Sci. 6(5): 1105-1123. doi: https://doi.org/10.20546/ijcmas.2017.605.120 